\title{
Population should be on the Johannesburg agenda
}

\author{
High fertility rates continue to threaten both the environment and human well-being.
}

Sir - On 26 August, the United Nations

(UN) World Summit on Sustainable Development in Johannesburg will consider strategies with a far broader mandate for action than the UN Conference on Environment and Development in Rio de Janeiro in 1992. Population as a key component of sustainable development should figure prominently on the Johannesburg agenda. Yet, after four preparatory meetings for Johannesburg, the topic is still absent.

If we do not put the human population at the core of the sustainable-development agenda, our efforts to improve human well-being and preserve the quality of the environment will fail.

The Johannesburg Summit must heed the first principle of the 1992 Rio Declaration - that "human beings are at the centre of concern for sustainable development" - by taking full account of how population and society interact with the natural environment. This is one of the basic conclusions of the Global Science Panel on Population and Environment, an independent body of experts organized by the International Institute for Applied Systems Analysis (IIASA), the International Union for the Scientific Study of Population and the United Nations University.

Sustainable development aims at improving human well-being, particularly through alleviating poverty, increasing gender equity, and improving health, human resources and stewardship of the natural environment. Because demographic factors are closely linked to these goals, strategies that take population into account have a better chance of success.

The International Conference on Population and Development in Cairo in 1994 recognized that population policy should be oriented towards improving social conditions and expanding choices for individuals. The key recognition was that focusing on people - their rights, capabilities and opportunities - would have multiple benefits for individuals, for societies and for their sustainable relationship with the environment. Therefore, in Johannesburg, consideration of sustainable-development policies must include population growth and distribution, mobility, health impacts of environmental change, differential vulnerability, and the empowerment of people, especially of women.

Fertility decline in high-fertility countries, by slowing population growth, can make many environmental problems easier to solve. It can also have important economic benefits through reducing the number of children relative to the working-age population, creating a unique opportunity to increase investments in health, education, infrastructure and environmental protection.

In high-income countries, the environmental impact of population growth and distribution must be considered jointly with high consumption rates. Even in countries where little growth is envisioned, unsustainable patterns of consumption have global implications for the environment and human wellbeing, and must be addressed with appropriate policies.

Hence, on the way from Rio to Johannesburg we must go through Cairo. Two key policies are needed: first, investment in voluntary family planning and reproductive-health programmes; and second, education and empowerment, especially of women, in order to reduce fertility, enhance individual choice, contribute to greater environmental awareness and reduce vulnerability to environmental changes.

Wolfgang Lutz, Mahendra Shah Coordinators, Global Science Panel on Population and Environment (GSPPE), IIASA, Schlossplatz 1, A-2361 Laxenburg, Austria

Other signatories of this letter are the panel members of the GSPPE: R. E. Bilsborrow, J. Bongaarts, P. DasGupta, B. Entwisle, G. Fischer, B. Garcia, D. J. Hogan, A. Jernelov, Z. Jiang, R. W. Kates, S. Lall, F. L. MacKellar, P. K. Makinwa-Adebusoye, A. J. McMichael, V. Mishra, N. Myers, N. Nakicenovic, S. Nilsson, B. C. O'Neill, X. Peng, H. B. Presser, N. Sadik, W. C. Sanderson, G. Sen, M. F. Strong, B. Torrey, D. van de Kaa, H. J. A. van Ginkel, B. Yeoh, H. Zurayk.

Full address details and affiliations are available on the panel's

website at www.iiasa.ac.at/gsp

\section{Beautiful vistas, but is this really science?}

Sir — Negotiating Stephen Wolfram's vast book A New Kind of Science, on which you report in the News Feature "What kind of science is this?" (Nature 417, 216-218; 2002), reminded me of Huckleberry Finn's epic journey drifting down the Mississippi on a raft — not just the length, but the scenery.

On the left bank of the river we pass a long series of wondrously complex and often very beautiful pictures, the amazing products of his simple automata. On the right bank we drift by his conjectures and speculations about the meaning of these gorgeous images. He 'explains' nearly all the real world's puzzling phenomena, from particle physics to evolution of species.

How might we cross safely from the left bank of the river to the right? I found myself yearning for a solid bridge to link at least one of Wolfram's pictures to the real world, but unfortunately, all he offered was a leap of faith.

Which leads me to wonder: what did we really see on this long and dazzling journey? If it was 'science', even of a new kind, it should fulfil at least two criteria. First, it should be falsifiable: it should be possible to design an experiment to disprove a proposed link between the model and the real world. And second, it should generate new hypotheses about the real world which scientists can test in their laboratories. Perhaps Wolfram could enlighten us: how might his computer models fulfil either of these criteria in order to qualify as science? Michael Phillips

Menssana Research, 1 Horizon Road, Suite 1415, Fort Lee, New Jersey 07024, USA

\section{Solve postgrad problems to attract new scientists}

Sir - We agree with your Opinion article "Selling science to the young" (Nature 417, $1 ; 2002)$ that science should highlight those who turn their scientific training into a more lucrative career. Take, for example, Jan Peter Balkenende, who turned his economics professorship into a premiership after his Christian Democrat party won the Dutch elections in May.

However, it should be stressed that, in addition, the best way of countering the anti-science trend is to solve science's main problems. As you state, the young are refusing to choose a scientific education. Surely it is time to acknowledge fully the complaints of postgraduate associations, to discuss these and to offer improved career prospects and financial rewards? T. L. Raoul Tan ${ }^{\star}$, Simone Lohner $\dagger$ ${ }^{\star}$ Ex-president, European Council for Doctoral and Postdoctoral Students, Department of Cell Biology and Genetics, Erasmus University Rotterdam, PO Box 1738, 3000 DR Rotterdam, The Netherlands $\dagger$ President, LAIOO: the Dutch PhD student council, Instituut voor Leraren Opleiding, University of Amsterdam, Wibautstraat 2-4, 1891GM Amsterdam, The Netherlands 